Сіданіч Ірина Леонідівна доктор педагогічних наук, доцент, завідувач кафедри педагогіки, адміністрування і спеціальної освіти Навчально-наукового інституту менеджменту та психології ДЗВО «Університет менеджменту освіти», вул. Січових Стрільців, 52-а, м. Київ, 04053, тел.: (063) 754-32-80, e-mail: 2363395@ukr.net, https://orcid.org/0000-0003-0645-6781

\title{
ПЕДАГОГІЧНІ ПРАКТИКИ РОЗКРИТТЯ ДУХОВНОГО ПОТЕНЦАЛУ МАЙБУТНІХ ФАХІВЦІВ ОСВІТНЬОГО МЕНЕДЖМЕНТУ
}

Анотація. У статті розглядається психолого-педагогічні практики розкриття духовного потенціалу та можливості духовної самореалізації майбутніх фахівців освітнього менеджменту в просторі соціально-гуманітарного середовища університету на якісно новому рівні підготовки (самопідготовки) здобувача вищої освіти. Головною турботою для майбутнього менеджера освіти $є$ організація самовиховання та саморозвитку, розвиток уваги та уважності до людей i навколишнього середовища, щоб розуміти й врахувати все, що відомо про життя і про людей, зберігаючи віру в них. Педагогічна духовність - складний стан внутрішнього світу особистості фахівця. У цьому ії велика, нічим незрівнянна особистісна цінність, близька до совісті. Як будь-яка духовність, вона має зовнішні прояви, що роблять ії цінність соціальною. Керівники з високим рівнем духовного потенціаду і соціальної зрілості успішно реалізують виховні можливості організації освітнього процесу.

Аналіз проблеми розкриття духовного потенціалу здобувачів вищої освіти свідчить про те, що це $є$ одним 3 пріоритетних напрямів сучасної освітньої системи, де заклади вищої освіти за своїм статусом зобов'язані професійно готувати не тільки дипломованих фахівців, а й виховувати духовно розвинених громадян. Таке взаємовигідне поєднання можна вважати одним із найважливіших чинників оновлення духовного потенціалу здобувачів вищої освіти.

Духовний потенціал знань реалізується і в тому випадку, коли в процесі підготовки фахівців освітнього менеджменту їх пов'язують безпосередньо 3 науково-технічним прогресом, технологію сучасного виробництва, впливають з їх допомогою на вибір майбутньої професійної діяльності. Фахівець нового зразка має володіти цілим спектром духовних соціокультурних навичок. Практична реалізація визначеного завдання залежить насамперед від загальної культури фахівця здатного вільно орієнтуватися в соціальних і природних умовах, розуміти 
особливості розвитку культури, оволодівати науковою інформацією. Професіонал у галузі менеджменту освіти має глибоко усвідомлювати місце й роль освітніх процесів у світовому культурному просторі, поєднувати глибокі фундаментальні теоретичні знання й практичну підготовку.

Ключові слова: духовний потенціал; педагогічна духовність, фахівець освітнього менеджменту, психолого-педагогічні практики розкриття духовного потенціалу майбутніх фахівців.

Sidanich Iryna Leonidovna Doctor of Sciences in Pedagogy (Dr. Hab.), associate professor, Professor of the Department of Pedagogy, Administration and Social Work Educational and Scientific Institute of Management and Psychology SIHE «University of Educational Management», Sichovykh Striltsiv St., 52 A, Kyiv, 04053, tel.: (063) 754-32-80; e-mail: 2363395@ukr.net, https://orcid.org/0000-0003-0645-6781

\section{PEDAGOGICAL PRACTICES OF SPIRITUAL POTENTIAL DISCOVERY FUTURE EDUCATIONAL MANAGEMENT SPECIALISTS}

Abstract. The article considers psychological and pedagogical practices of revealing the spiritual potential and opportunities for spiritual self-realization of future specialists in educational management in the social and humanitarian environment of the university at a qualitatively new level of training (self-training) of higher education. The main concern for the future education manager is the organization of self-education and self-development, the development of attention and attention to people and the environment to understand and take into account everything that is known about life and people, while maintaining faith in them. Pedagogical spirituality is a complex state of the inner world of a specialist's personality. In this her great, incomparable personal value, close to conscience. Like any spirituality, it has external manifestations that make its value social. Leaders with a high level of spiritual potential and social maturity successfully implement the educational opportunities of the educational process.

Analysis of the problem of revealing the spiritual potential of higher education students shows that this is one of the priorities of the modern education system, where higher education institutions are obliged by their status to professionally train not only graduates but also to educate spiritually developed citizens. Such a mutually beneficial combination can be considered one of the most important factors in renewing the spiritual potential of higher education students.

The spiritual potential of knowledge is realized in the case when in the process of training specialists in educational management they are directly related to scientific and technological progress, technology of modern production, influence with their help on the choice of future professional activity. A specialist of a new type must have a whole 
range of spiritual socio-cultural skills. The practical implementation of a particular task depends primarily on the general culture of the specialist who is able to navigate freely in social and natural conditions, to understand the peculiarities of cultural development, to master scientific information. A professional in the field of education management must be deeply aware of the place and role of educational processes in the world cultural space, combine deep fundamental theoretical knowledge and practical training.

Keywords: spiritual potential; pedagogical spirituality, specialist in educational management, psychological and pedagogical practices of revealing the spiritual potential of future professionals.

Постановка проблеми. В сучасних умовах, коли людство в своїй взаємодії 3 довкіллям підійшло до кризового стану, визначальним фактором існування стає формування духовного потенціалу, в якому відображена міра можливостей актуалізації духовних сил особистості цілеспрямованій соціокультурній діяльності. Адекватний світові і людському буттю, тобто виявленню соціальних $\mathrm{i}$ духовних джерел можливостей, резервів і засобів цілеспрямованої діяльності, він забезпечує прогрес особистості і суспільства в цілому. Характерний для розвитку сучасного суспільства динамізм, нарощування його духовного потенціалу, утвердження суб'єктної позиції особистості висувають якісно нові вимоги до особистості вчителя, рівня його вивченості і професійної компетентності.

Сучасна духовна криза призвела до розпаду звичних форм організації життя, втрати ідеалів, ерозії та деформації системи цінностей, різкого падіння моральності. Духовності потрібно вчити, як вчать іншим предметам. Важливо ліквідувати етичну та психологічну неграмотність нашої молоді, яка в процесі освіти отримує безліч знань у різних галузях, але не володіє знаннями про себе як про особистість, іiі духовну основу, моральні аспекти поведінки.

Сутність освітнього процесу становить формування здатності особистості до самореалізації у різних галузях людської життєдіяльності за умов урахування необхідності саморозкриття інших людей. Внаслідок цього головною ціннісною установкою стратегії реформування освіти в Україні повинна стати націленість на духовне збагачення і творчу діяльність особистості, що розвиває свої здібності до самореалізації та створення умов для саморозкриття інших людей. Для української системи освіти такими цінностями $є$ цінності людської гідності, соціальної ініціативи і творчості, патріотизму, національної свідомості.

Найбільш значимими цінностями для соціально-гуманітарної освіти $\epsilon$ : 1) відповідальність за загальнозначущі цінності; 2) загальнокультурна компетентність; 3) вільні ціннісні самовизначення; 4) особистісна самоактуалізація в культурі і житті. Разом з тим відкритою залишається проблема конкретизації виявлення освітніх цінностей у цілях, нормах, вимогах, котрі 
стосуються різноманітних аспектів соціально-гуманітарної освіти.

Аналіз останніх досліджень і публікацій свідчить, що менеджмент у вищій освіті - це комплекс принципів, методів, організаційних форм і технологічних прийомів управління освітніми процесами, спрямованими на підвищення ефективності таких процесів в умовах розвитку ринку освітніх послуг. Оскільки в реальному функціонуванні закладів вищої освіти мають місце два специфічних процеси управління й адміністрування, то менеджерів освіти диференціюють саме у такий спосіб. Менеджер освітнього процесу - це керівник вищого навчального закладу освіти (ректор) чи його заступник (проректори з навчальної, наукової, виховної та господарської роботи; директори інститутів, декани факультетів; завідувачі кафедр), який спеціально підготовлений до успішного керування людьми в ринкових умовах господарювання і виступає як суб'єкт управління цілісною педагогічною системою - професійною діяльністю педагогічних працівників і допоміжного персоналу.

Мета статті - визначити педагогічні умови формування духовних цінностей здобувачів вищої освіти у сфері освітнього менеджменту. Теоретичні засади нашої розвідки - вивчення освітньо-професійних програм, новітніх літературних джерел та аналітичних документів навчально-наукових та громадських установ, які стосуються підготовки майбутнього фахівця освітнього менеджменту.

Виклад основного матеріалу. Менеджер освітнього процесу - викладач, доцент, професор, тобто професійно підготовлений фахівець, який є керівником та організатором життя молодого покоління майбутніх спеціалістів у нових ринкових соціально-економічних умовах, і постає як суб'єкт системи управління навчально-пізнавальною діяльністю студентів. Очевидно, що за нових умов ринкової економіки оволодіння основами менеджменту в освіті допоможе кожному з педагогічних працівників більш успішно вирішувати власні професійні проблеми, ефективно здійснювати функції самоменеджменту в сфері педагогічної діяльності (управління собою), формулювати чіткі особистісні цілі, раціонально використовувати час, кваліфіковано переробляти і використовувати інформацію.

Кардинальна зміна суспільних відносин, коли кожен із працівників системи вищої освіти зазнає стресів та стикається 3 невизначеністю, коли розмивання традиційних цінностей призвели до серйозного розладу власних переконань та моральних орієнтирів, висуває необхідність вибудовувати свої власні цінності, визначати чіткі життєві й виробничі цілі. Це зумовлене тим, що традиційні ієрархічні професійно-педагогічні відносини порушені, авторитарний стиль не спрацьовує, а продуктивна праця потребує нових способів впливу на студентів, не вдаючись до наказів, тиску, «влади професії», перед викладачами виникла величезна кількість духовно-моральних, етичних, матеріальних та інших проблем, які потрібно вміти вирішувати. Усе це сприяло посиленню інтересу педагогічних 
працівників до сучасного менеджменту в освіті.

На відміну від традиційно вживаного у вітчизняній психолого-педагогічній літературі поняття «керування», термін «менеджмент» більш адекватно враховує нові реалії педагогічної дійсності, зумовлені дією нових засобів та інноваційних технологій навчання. Тому ознайомлення з теорією педагогічного менеджменту i самоменеджменту допоможе викладачу вищої школи по-новому осмислити сутність своєї професійної ролі саме як фахівця нового типу - менеджера освітнього процесу, тобто організатора та диспетчера пошукової, експериментально-дослідної та професійної діяльності здобувачів вищої освіти як майбутніх фахівців, побачити в ній нові аспекти, зрозуміти, як зробити власну працю більш відповідною потребам сучасності.

Результативність дослідження формування духовних цінностей здобувачів вищої освіти у сфері освітнього менеджменту визначається процесами опрацювання, засвоєння та використання знань. Теоретичний рівень пізнання процесів трансформації пов'язаний із використанням системного підходу. Принцип системності, як невід’ємний елемент діалектичного методу дослідження, органічно взаємопов'язаний із принципами розвитку, єдності й боротьби суперечностей, історизму тощо. Дослідження соціокультурних трансформацій базуються на комплексному застосуванні цих логічних принципів, кожен 3 яких об’єднує низку більш конкретних прийомів, правил, засобів пізнання.

Формування духовних цінностей здобувачів вищої освіти як один із пріоритетних напрямів освітнього менеджменту має певні особливості за наявності кількох об'єктивних причин.

Розвиток теорії управління освітою викликав безліч нетрадиційних трактувань цього явища, а внаслідок цього й у практичній діяльності з керування освітнім процесом виникли такі поняття, як педагогічний менеджмент, дидактичний менеджмент, менеджери освіти, менеджери освітнього процесу. Педагогічний і дидактичний менеджмент, що розвиваються в межах освітнього менеджменту, мають свою специфіку у зв'язку з виконанням особливої функції створенням систем управління педагогічними і дидактичними процесами.

Як бачимо, протиріччя між потребою особистості в духовному розвитку i станом процесу формування в сучасному вузі загострюється системною духовною кризою. У такій ситуації необхідність переакцентування цілей освіти на духовність стає очевидною. Ціннісною підставою формування повинна стати орієнтація на духовність особистості студента, оволодіння ним світових i національних надбань.

Назріла необхідність у теоретичній розробці проблем духовності, у реальному поверненні категорії «духовність» у педагогічну науку i практику. Довіра до рівня духовної культури високо цінується молоддю, стимулює 
взаємність, відвертість у спілкуванні 3 викладачами. Ситуація відкритості дозволяє з більшою глибиною й ефективністю коректувати інтереси студентів, направляти їхні потреби.

Головною сферою соціальної активності студентства $\epsilon$ навчання. По відношенню до неї випробовуються різні види духовної культури, вона служить своєрідним індикатором громадянської зрілості, розуміння своїх прав і обов’язків. Досягнутий студентами рівень духовності імпліцитно присутній в організації занять, культурі читання спеціальної літератури, оцінці значимості знань, що здобуваються, мотивації навчальної діяльності.

Таким чином, рівень духовної культури студентів, ï окремих видів безпосередньо відбивається на інтенсивності і спрямованості соціальної активності. Естетична, моральна, політична культура визначає ціннісні орієнтації студентів на ті чи інші сфери застосування своїх здібностей, рівень їх прагнень. Вона допомагає зосередити сили на найбільш прийнятному для майбутнього фахівця полі діяльності, знайти своє місце в житті. Між ступенем засвоєння духовної культури і соціальною активністю існує діалектичний взаємозв'язок. Отже, за продукти духовного виробництва ми приймаємо мрії, ідеали, уявлення, почуття прекрасного, моральні норми, забобони, тобто все те, що існує в голові людини, яка живе цим, страждає, радіє чи засмучується.

Духовність є ціннісною підставою виховання особистості. Нині питання формування духовного розвитку людини актуалізує проблеми виховання людяності, що плідно можуть бути вирішені з позиції ідеалістичної концепції людини. Даний підхід пояснює численні факти існування людини крізь призму їі духовної сутності, що піднімає іiі до рівня інтенції, до вічних цінностей. Дихотомічна природа людини не заперечує іï духовної сутності, оскільки втрата повноти життя як основного атрибута духовності може позбавити іiі реальної екзистенції, але не особистісного призначення. Наявна екзистенція, як осередок особистісного буття людини, духовно передбачає всю іiі іпостась (індивід, суб'єкт, особистість).

Однак духовність, імпліцитно включена в загальну мету, не завжди стає іiі справжньою підставою, у цьому зв’язку виникає потреба у виділенні спеціального процесу формування і виховання духовності, оскільки вона є умовою наступності поколінь. Процес формування духовності студентів є педагогічним явищем. Це взаємодія педагог-студент, що включає такі етапи, як цілепокладання, переживання, осмислення, відношення, саморефлексія, моделювання, подолання тощо $[1-13 ; 3]$.

Якщо обгрунтувати педагогічний аспект духовності, то це вирішить завдання щодо аргументації положення про духовність як результат формування i виховання, що приводить до становлення цілісної особистості, багатої духовним, 
смислобуттєвим змістом.

Підготовка магістрів педагогіки вищої школи в Україні відбувається в умовах перебудови змісту вищої освіти, удосконалення навчальних програм, підготовки нових курсів та спецкурсів, які б відповідали рівню кваліфікації випускника, сприяли формуванню основних професійних компетенцій майбутнього викладача християнської педагогіки у вищій школі.

У сучасний період розвитку та реформування вищої освіти значну наукову цінність має звернення вчених, практиків до наявного освітньо-виховного досвіду, висвітлення закономірностей, що можуть бути основою для процесу експериментальної діяльності щодо запровадження спеціалізації «Християнська педагогіка», «Християнський менеджмент».

Зазначене дає підстави для формування мети, змісту, обсягу i завдань управління професійно-педагогічною підготовкою магістрів. Так, в Навчальнонауковому інституті менеджменту та психології ДЗВО «УМО» управління підготовкою викладачів у магістратурі здійснюється відповідно до чинних освітньо-кваліфікаційних характеристик та освітньо-професійних програм, затверджених ректором у новому навчальному році. Дисципліни професійної та практичної підготовки викладача університетів і вищих навчальних закладів відображено в навчальному плані магістратури за спеціальністю «Педагогіка вищої школи». Зазначений документ містить нормативні навчальні й елективні дисципліни за вибором професійно-педагогічного змісту на провідній кафедрі управління навчальним закладом та педагогіки вищої школи [4; 5].

Проблема стандартизації у підготовці спеціалістів 3 викладання предметів духовно-морального спрямування, зокрема майбутніх магістрів за спеціалізацією «Християнська педагогіка» виникає під час розроблення освітньо-кваліфікаційної характеристики $(\mathrm{OKX})$ випускника вищого навчального закладу, що має бути державним нормативним документом, в якому узагальнюється зміст освіти, тобто відображаються цілі освітньої та професійної підготовки, визначається місце магістра педагогіки вищої школи 3 відповідною спеціалізацією у структурі господарства держави i вимоги до його компетентності, інших соціально важливих властивостей та якостей.

Відмітимо, що такий стандарт має бути варіативною складовою у галузевій компоненті державних стандартів вищої освіти, в якій узагальнюються вимоги 3 боку держави, християнського духовенства, світового співтовариства та споживачів, випускників до змісту освіти і навчання. Також ОКХ відображає соціальне замовлення на підготовку фахівця з урахуванням аналізу професійної діяльності випускника вищого навчального закладу — магістра педагогіки вищої школи і державні та духовно-моральні вимоги до властивостей та якостей особи, яка здобула базову вищу освіту відповідного фахового спрямування та 
спеціалізації «Християнська педагогіка».

Відповідно до Указу Президента України від 13 жовтня 2015 року № 580/2015, затверджено Стратегію національно-патріотичного виховання дітей та молоді на 2016-2020 роки, в якій основними складовими національнопатріотичного виховання мають стати громадянсько-патріотичне, військовопатріотичне, духовно-моральне виховання. Одним 3 основних напрямів досягнення мети Стратегії визначено впровадження навчальних дисциплін духовно-морального спрямування як основи формування особистості та підгрунтя для національно-патріотичного виховання. Це потребує підготовки висококваліфікованих фахівців, для яких і було розроблено ОПП «Християнська педагогіка» $[6 ; 7 ; 8]$.

Ми вважаємо за потрібне введення до навчального плану підготовки магістрів за ОПП «Християнська педагогіка» такі навчальні дисципліни: «Основи християнської педагогіки», «Християнська духовність», «Основи християнської моралі i етики», «Методика викладання предметів духовно-морального спрямування». Діяльність магістра-викладача християнської педагогіки вищої школи відбувається у площині предметного поля «Християнська педагогіка $\mathrm{i}$ психологія», тому основні дисципліни, які він має засвоїти за півтора роки, присвячені основним закономірностям i тенденціям розвитку психологопедагогічних та біблійно-теологічних наук

Ці навчальні дисципліни покликані зорієнтувати майбутніх фахівців в специфіці формування духовного потенціалу особистості, розкрити гуманістичні аспекти педагогічної діяльності, на ціннісно-методологічній основі сформувати концептуальні позиції, спрямовані на збереження та розвиток духовності української нації. Педагогіка духовного потенціалу особистості в системі сучасного людинознавства Лекція 1. Методологічні засади розвитку духовного потенціалу особистості Філософські основи педагогіки духовного потенціалу особистості. Детермінанти і типи духовності. Аксіологічні імперативи педагогіки духовного потенціалу особистості[ $[9 ; 10]$.

Лекція 2. Напрями розвитку педагогіки духовного потенціалу особистості Педагогічна генеза духовного потенціалу особистості. Роль педагогічної антропології в розробці проблеми духовного потенціалу особистості. Сучасні підходи психолого-педагогічної науки до проблеми формування духовного потенціалу особистості.

Лекція 3. Духовний потенціал особистості: сутність, специфіка проблеми формування Духовні сутнісні сили людини, їх структура та специфіки. Творча самореалізація особистості як прояв актуалізації духовних i пісних сил. Морально-естетичний досвід - інтегральна основа духовного потенціалу особистості. Лекція 4. Структурні компоненти духовного потенціалу особистості 
Духовні почуття в структурі духовного потенціалу особистості. Нормативнорегулятивні механізми духовного потенціалу особистості. Предметна детермінованість духовного потенціалу особистості

Організаційно-методична система формування духовного потенціалу особистості Лекція 5. Загальна характеристика системи формування духовного потенціалу особистості. Загальна характеристика системи формування духовного потенціалу особистості. Джерела і принципи формування духовного потенціалу особистості. Соціально-педагогічні умови формування духовного потенціалу особистості. Література основна: 1, 2, 5. Література додаткова: 24, 30, 31. Лекція 6. Соціалізація і формування духовного потенціалу особистості Фактори формування духовного потенціалу особистості (сім'я, народні традиції, релігійні общини, молодіжні об'єднання). Мистецтво як засіб формування духовного потенціалу особистості. Засоби масової інформації в системі формування духовного потенціалу особистості.

Підготовка магістра-викладача християнської педагогіки вимагає i педагогічної підготовки. Студенти мають можливість поглибити свої знання, сформувати професійні вміння та навички на заняттях 3 «Педагогіки вищої школи», «Дидактичних систем у вищій освіті», «Моделювання освітньої діяльності». «Методик викладання навчальних дисциплін духовно-морального виховання у вищій школі», а також упродовж восьмитижневої педагогічної (асистентської) практики $[11 ; 12 ; 13]$.

Отже, у процесі управління професійною підготовкою майбутніх викладачів християнської педагогіки у вищій школі відбувається теоретична та практична підготовка студента до майбутньої професійної діяльності. Особистісне зростання, набуття теоретичного багажу та практичного досвіду пов'язане насамперед із творчим характером навчального процесу та його успішного засвоєння майбутнім викладачем, що одночасно підкріплюється розвитком критичного мислення, емоційної наповненості, особистісної зрілості та творчого пошуку.

Висновки. Отже, важливим напрямом підготовки магістрів-викладачів педагогіки у вищій школі за спеціалізацією «Християнська педагогіка». «Університет менеджменту освіти» є поглиблення конструктивного діалогу між представниками богословської та світської науки, розроблення нових наукових напрямів співпраці, підготовка навчально-методичних посібників, підручників, концепцій виховання та освіти, які б, з одного боку, враховували християнські традиції, а з іншого - тенденції розвитку сучасної науки. Викладачі християнської педагогіки покликані постійно шукати нові шляхи до пізнання Істини, знаходити ключі до сердець і розуму студентської молоді. Ефективна національна система вищої освіти є не тільки найважливішим, ключовим напрямом роботи вищого 
навчального закладу, а найважливішим ресурсом, засобом розвитку священної місії сучасної освіти. Право вільного вибору переконань має зберігатися за кожним і $\epsilon$ особистою справою індивіда. Це означає, що релігія має бути представлена в освіті України не у вигляді ідеології, а як складова наукового знання про людину і суспільство внаслідок їх іманентної культурної цінності. Християнська педагогіка має формувати у молоді довіру до традиційних духовних цінностей українського суспільства, толерантність стосовно до інших релігійних вірувань.

\section{Jimepamypa:}

1. Радул. В.В. Фактори соціальної зрілості студентів педвузу / В.В. Радул. - Київ, 1994, $144 \mathrm{c}$.

2. М. В. Гриньова, «Проект підготовки магістра напряму "Педагогічна освіта" спеціальності "Християнська етика" на кафедрі педагогічної майстерності та менеджменту Полтавського педагогічного університету», Стратегія духовного розвитку України: єдність духу в союзі миру, на III Покровських міжнар. місіонерсько-просвіт. читань (26-28 жовт. 2010 р.). Полтава, Україна: ТОВ «АСМІ», 2010, с. 24-31.

3. М. Лагодич, «Місце та роль релігійної освіти у громадянському суспільстві», Науковий вісник Чернівецького університету: зб. наук. праць. Чернівці, Україна: Золоті литаври, Вип. 203/204, 2004. (Серія «Філософія»).

4. Н. І. Мачинська, Педагогічна освіта магістрантів вищих навчальних закладів непедагогічного профілю: монографія; С. О. Сисоєва, Ред. Львів, Україна: ЛьвДУВС, 2013, 416 с.

5. Педагогічний словник; М. Д. Ярмаченка, Ред. Київ, Україна: Пед. думка, 2001, 478 с.

6. Пріоритети державної політики в галузі свобод совісті: иляхи реалізації: зб. наук. матеріалів. Київ, Україна: Світ Знань, 2007.

7. «Релігійні організації в Україні (станом на 1.01.2010)», RISU, Реліzійно-інформаційна служба України. [Електронний ресурс]. Доступно: https://risu.org.ua/ua/index/esourses/ statistics/ukr2010

8. «Рівень і характер релігійності українського суспільства», Держсвно-конфесійні відносини в Украӥні, їх особливості $і$ тендениії розвитку, інформац.-аналіт. матеріали до «круглого столу» на тему: Релігія і влада в Украӥні: проблеми взаємовідносин (8 лют. 2011 р.). Київ, Україна: Центр Разумкова, 2011.

9. Г. Робберс, Государство и религии в европейском союзе; М. А. Воскресенского, А. А. Красикова, Р. Н. Лункина [и др.], Ред. Москва, Россия: Ин-т Европы РАН, ТЦ Юнеско, 2009.

10. Статут вищого навчального закладу «Український католицький університет» (нова редакиія). [Електронний ресурс]. Доступно: http://ucu.edu.ua/files/2015/06/statut-vnz-uku2015_080615.pdf

11. М. Й. Боришевський, «Духовні цінності як детермінанта розвитку й саморозвитку особистості», Педагогіка і психологія, № 2, с.18-22, 2008.

12. Ю. С. Кайданович, «Формування управлінської культури державного службовця в галузі освіти», Інвестииії: практика та досвід, № 12, с. 103-106, 2011.

13. Л. В. Ткачук, «Духовно-моральні цінності у професійному становленні особистості майбутнього вчителя», Професійна освіта: методологія, теорія та технології, № 2, c. 201-215, 2015. 


\section{References:}

1. Radul. V.V. Faktori social'noï zrilosti studentiv pedvuzu / V.V. Radul. - Kiïv, 1994, - 144 s.

2. M. V. Grin'ova, «Proekt pidgotovki magistra naprjamu "Pedagogichna osvita" special'nosti "Hristijans'ka etika" na kafedri pedagogichnoï majsternosti ta menedzhmentu Poltavs'kogo pedagogichnogo universitetu», Strategija duhovnogo rozvitku Ukraïni: ednist' duhu v sojuzi miru, na III Pokrovs'kih mizhnar. misioners'ko-prosvit. chitan' (26-28 zhovt. 2010 r.). Poltava, Ukraïna: TOV «ASMI», 2010, s. 24-31.

3. M. Lagodich, «Misce ta rol' religijnoï osviti u gromadjans'komu suspil'stvi», Naukovij visnik Chernivec'kogo universitetu: zb. nauk. prac'. Chernivci, Ukraïna: Zoloti litavri, Vip. 203/204, 2004. (Serija «Filosofija»).

4. N. I. Machins'ka, Pedagogichna osvita magistrantiv vishhih navchal'nih zakladiv nepedagogichnogo profilju: monografija; S. O. Siso€va, Red. L'viv, Ukraïna: L'vDUVS, 2013, 416 s.

5. Pedagogichnij slovnik; M. D. Jarmachenka, Red. Kiïv, Ukraïna: Ped. dumka, 2001, 478 s.

6. Prioriteti derzhavnoï politiki v galuzi svobod sovisti: shljahi realizaciï: zb. nauk. materialiv. Kiïv, Ukraïna: Svit Znan', 2007.

7. «Religijni organizaciï v Ukraïni (stanom na 1.01.2010)», RISU, Religijno-informacijna sluzhba Ukraïni. [Elektronnij resurs]. Dostupno: https://risu.org.ua/ua/index/resourses/ statistics /ukr2010

8. «Riven' i harakter religijnosti ukraïns'kogo suspil'stva», Derzhavno-konfesijni vidnosini v Ukraïni, ïh osoblivosti i tendenciï rozvitku, informac.-analit. materiali do «kruglogo stolu» na temu: Religija i vlada v Ukraïni: problemi vza€movidnosin (8 ljut. 2011 r.). Kiïv, Ukraïna: Centr Razumkova, 2011.

9. G. Robbers, Gosudarstvo i religii v evropejskom sojuze; M. A. Voskresenskogo, A. A. Krasikova, R. N. Lunkina [i dr.], Red. Moskva, Rossija: In-t Evropy RAN, TC Junesko, 2009.

10. Statut vishhogo navchal'nogo zakladu «Ukraïns'kij katolic'kij universitet» (nova redakcija). [Elektronnij resurs]. Dostupno: http://ucu.edu.ua/files/2015/06/statut-vnz-uku-2015_080615.pdf

11. M. J. Borishevs'kij, «Duhovni cinnosti jak determinanta rozvitku j samorozvitku osobistosti», Pedagogika i psihologija, № 2, s.18 - 22, 2008.

12. Ju. S. Kajdanovich, «Formuvannja upravlins'koï kul'turi derzhavnogo sluzhbovcja v galuzi osviti», Investiciï: praktika ta dosvid, № 12, s. 103-106, 2011.

13. L. V. Tkachuk, «Duhovno-moral'ni cinnosti u profesijnomu stanovlenni osobistosti majbutn'ogo vchitelja», Profesijna osvita: metodologija, teorija ta tehnologii, № 2, s. 201-215, 2015. 